\title{
Identifying Buffalograss [Buchloe dactyloides (Nutt.) Engelm.] Cultivar Breeding Lines Using Random Amplified Polymorphic DNA (RAPD) Markers
}

\author{
Lin Wu and Hong Lin \\ Department of Environmental Horticulture, University of California, Davis, CA 95616 \\ Additional index words. cultivar identification, DNA extraction methods, DNA fingerprints, ploidy
}

\begin{abstract}
The polymerase chain reaction (PCR) and RAPD fragments are potentially useful methods for identifying turfgrass cultivar breeding lines. RAPD markers were studied in 25 vegetatively propagated buffalograss lines using oligonucleotide random primers and agarose-gel electrophoresis to determine their potential for identifying cultivar breeding lines. The variation of RAPD markers was extensive. The RAPD markers produced by one random primer were sufficient to separate the 25 buffalograss lines. Cluster analysis baaed on' the RAPD markers produced by two random primers revealed that the 25 buffalograss lines generally fell into two groups: diploid and hexaploid. Three DNA extraction methods-sarcosyl lysis-chloroform extraction-isopropanol precipitation, sodium dodecyl sulfate (SDS) lysine-isopropanol precipitation, and boiling in the presence of Chelex-100 resin-and fresh or oven-dried tissues were tested for reproducibility of RAPD markers. The three DNA extraction methods, using dry or fresh plant tissues, produced highly comparable RAPD marker profiles. More than $80 \% 1$ of the RAPD markers was consistently detected in six replicate analyses. The above studies demonstrate that small quantities $(5 \mathrm{mg})$ of oven-dried leaf tissue and several DNA extraction methods can be used for buffalograss fingerprint studies.
\end{abstract}

The technology of polymerase chain reaction (PCR) and RAPD fragments (Williams et al., 1990) is potentially useful for identifying cultivar breeding lines. Amplifying single-locus minisatellites by PCR using specific flanking primers (Jeffreys et al., 1988, 1985) and mapping repeated sequences have also produced individual-specific fingerprints. Recently, DNA polymorphisms amplified by oligonucleotide primers, 9 or 10 nucleotides in length or longer, were used as genetic markers (Gustavo et al., 1991; Hu and Quiros, 1991; Williams et al., 1990) for fingerprinting.

Identifying cultivar breeding lines is critical for turfgrass industries to control germplasm quality and protect their rights. Identifying phenotypes based on morphological traits involves a lengthy survey of plant growth that is labor intensive and vulnerable to environmental conditions. As art alternative, in the last 2 decades, isoenzyme and protein electrophoresis methods have been developed to identify turfgrass cultivar breeding lines (Clark et al., 1989; Hayward and McAdam, 1977; Villamil et al., 1982; Wehner et al., 1976; Wilkinson and Beard, 1972; Wu et al. 1984). The limited amount of polymorphism that can be detected among closely related genotypes is a disadvantage of these methods. In addition, the quality and quantity of isoenzymes and proteins maybe subject to variation in environmental conditions during plant growth and development. DNA-based procedures and genetic markers have been proposed for improving turfgrass identification.

Several grasses have been emphasized as alternative turfgrasses for energy conservation. The most notable of these is buffalograss, which is native to the shortgrass prairie of the United States and the central basin of Mexico. It contains diploid, tetraploid, and hexaploid races. Diploid and tetraploid races are restricted to areas in central Mexico, southern Texas, and New Mexico.

Received for publication 19 Nov. 1992. Accepted for publication 24 May 1993. Research was supported by the Agricultural Experimental Station Project, Univ. of California, Davis, CA-D8-EHT 4063-H, and research awards offered by the Northern California Turfgrass Council. We thank Carolyn Napoli of the Dept. of Environmental Horticulture, Univ. of California, Davis, for technical advice during this research. The cost of publishing this paper was defrayed in part by the payment of page charges. Under postal regulations, this paper therefore must be hereby marked advertisement solely to indicate this fact.
Buffalograss germplasm used for turfgrass breeding programs was collected over a wide geographical range by turfgrass breeders. Therefore, substantial genetic variation may exist among the newly developed buffalograss cultivars and breeding lines. Several new buffalograss cultivars are expected in the market. An efficient method to identify cultivars and their breeding lines is needed for this species. Herein, we report using RAPD markers to identify buffalograss genotypes. For turfgrass DNA fingerprinting, the availability of fresh plant samples can be a problem. Therefore, fresh and oven-dried turfgrass tissues were tested using three DNA extraction methods.

\section{Materials and Methods}

Plant materials. The 25 vegetatively propagated buffalograss lines tested (Table 1) include 12 diploid $(2 n=20)$ and 12 hexaploid $(2 n=60)$ lines and 1 tetraploid $(2 n=40)$ line. Most of these buffalograss lines were included in the National Turfgrass Evaluation Program and were supplied by the program. For the chromosome number study, the root-tip cells and pollen mother cells were examined using Fulgen stain and aceto-carmine methods described by Wu and Jampates (1986).

DNA extraction methods and consistency of RAPD profiles. For DNA extraction and primer selection, greenhouse-grown fresh leaf materials of the diploid buffalograss line Highlight 4 were used. The sarcosyl lysis-chloroform extraction-isopropanol precipitation method described by Dellaporta et al. (1983) was used with $100 \mathrm{mg}$ fresh leaf materials. Sixteen different oligonucleotide (10 nucleotide) random primers supplied by Operon Technologies (Alameda, Calif.) were prepared following the manufacturer's directions and used for the preliminary screening studies.

Three DNA extraction methods were compared. Primers A-9 and A-11 were used on fresh or dry leaf materials of Highlight-25 buffalograss (randomly chosen from the 25 vegetatively propagated buffalograss lines) to examine the consistency of RAPD markers produced by the three DNA extraction methods. The sarcosyl lysis-chloroform extraction-isopropanol precipitation 
Table 1. Sources and ploidy levels of the 25 buffalograss cultivar breeding lines used for the RAPD marker studies.

\begin{tabular}{lll}
\hline \hline Buffalograss & Ploidy & \\
line & level & Source \\
\hline AZ143 & Hexaploid & Univ. of Arizona \\
Bison & Hexaploid & Sharps Brothers Co. \\
Bufflawn & Diploid & Quality Turf INC \\
Highlight 4 & Diploid & Univ. of California, Davis \\
Highlight 15 & Diploid & Univ. of California, Davis \\
Highlight 25 & Diploid & Univ. of California, Davis \\
Highlight 911 & Diploid & Univ. of California, Davis \\
Highlight 912 & Diploid & Univ. of California, Davis \\
Highlight 92 & Diploid & Univ. of California, Davis \\
NE84-315 & Hexaploid & Univ. of Nebraska \\
NE84-436 & Hexaploid & Univ. of Nebraska \\
NE84-453 & Hexaploid & Univ. of Nebraska \\
NE84-609 & Hexaploid & Univ. of Nebraska \\
NE85-378 & Hexaploid & Univ. of Nebraska \\
NTDG-1 & Hexaploid & Native Turfgrass Group \\
NTDG-2 & Hexaploid & Native Turfgrass Group \\
NTDG-3 & Hexaploid & Native Turfgrass Group \\
NTDG-4 & Hexaploid & Native Turfgrass Group \\
NTDG-5 & Hexaploid & Native Turfgrass Group \\
Prairie & Tetraploid & Univ. of Texas \\
Rut-T-4-7 & Diploid & Rutgers Univ. \\
Rut-T-2-1 & Diploid & Rutgers Univ. \\
Rut-T-2-3 & Diploid & Rutgers Univ. \\
Rut-T-3-3 & Diploid & Rutgers Univ. \\
Rut-T-4-2 & Diploid & Rutgers Univ. \\
\hline
\end{tabular}

method described by Dellaporta et al. (1983) was used with $100 \mathrm{mg}$ greenhouse-grown fresh leaf tissue or $20 \mathrm{mg}$ of oven-dried (60C for $24 \mathrm{~h}$ ) leaves. This is a traditional method for extracting large amounts of DNA (50 $\mu \mathrm{g}$ or more). The sodium dodecyl sulfate (SDS) lysis-isopropanol precipitation method for rapidly preparing genomic DNA using small leaf disks for PCR analysis was introduced by Edwards et al. (1991). It was used for $10 \mathrm{mg}$ fresh or $5 \mathrm{mg}$ dried buffalograss leaf tissue in this study. A DNA extraction method using Chelex-100 chelating resin for extracting DNA from forensic-type samples described by Walsh et al. (1991) was also used for the present study.

For the Chelex- 100 extraction method, $10 \mathrm{mg}$ fresh or $5 \mathrm{mg}$ dried buffalograss leaf tissue was ground in liquid $\mathrm{N}$ in a small porcelain mortar and suspended in $1 \mathrm{~cm}^{3}$ distilled water. The leaf materials were then transferred to a $1.5-\mathrm{cm}^{3}$ Eppendorf tube. The following steps were followed: spin at 14,000 rpm for $3 \mathrm{~min}$ in a cold room, discard the supernatant, add $50 \mu \mathrm{l}$ 5\% Chelex-100 resin, vortex for 10 see, place in 56C water bath for 30 rein, vortex for 10 see, place in $100 \mathrm{C}$ water bath for 8 rein, vortex for 10 see, spin at $14,000 \mathrm{rpm}$ for $8 \mathrm{~min}$ in a cold room, and collect the supernatant for PCR. These Chelex procedures result in denatured sample DNA, therefore, the DNA is not suitable for RFLP analysis.

For PCR, the sample DNA concentration was determined using a spectrophotometer at $260 \mathrm{~nm}\left(1.0 \mathrm{OD}=50 \mu \mathrm{g} \mathrm{cm}{ }^{3}\right)$. DNA amplification was modified from the protocol reported by Williams et al. (1990). DNA amplification was performed in $25 \mu \mathrm{l}$ of reaction mixture containing $10 \mathrm{~mm}$ tris- $\mathrm{HCl}, \mathrm{pH} 8.3 ; 50 \mathrm{~mm} \mathrm{MgC1}_{2}$; $0.01 \%$ Triton-100; $1.25 \mu \mathrm{l}$ of $2 \mathrm{~mm}$ of each dATP, dTTP, dCTP, and dGTP (Boehringer Mannheim Co., Indianapolis); $1 \mu \mathrm{l}$ primer (10-mer RAPD Kits, Operon); and $20 \mathrm{ng}$ target DNA (260 nm/280 run ratio 1.8$)$.

To amplify DNA, a Tempcycler (Coy Corp., Ann Arbor, Mich.) was programmed for 45 cycles at $92 \mathrm{C}$ for $1 \mathrm{~min}, 38 \mathrm{C}$ for $1 \mathrm{tin}$, and $72 \mathrm{C}$ for 2 min for denaturing, annealing, and primer extension, respectively. After DNA amplification was complete, $10 \mu \mathrm{l}$ of the DNA samples was loaded on $2.0 \%$ agarose gel in $1 \mathrm{x}$ tris acetate EDTA buffer and run at $75 \mathrm{~V}$ for $\approx 3 \mathrm{~h}$. pGEM DNA markers (Promega, Madison, Wis.) were used as molecular standards. The gel was stained with $10 \mathrm{mg}$ ethidium bromide/liter for $30 \mathrm{~min}$ and then destained with tap water for $10 \mathrm{~min}$ and photographed under ultraviolet light with Polaroid 667 film. Each amplification product was identified by its size in base pairs (Gustavo et al., 1991). To determine the consistency of RAPD profiles produced by the three DNA extraction methods (above), six separate DNA extractions and RAPD analyses were conducted using primer A-9 or A11. RAPD markers were compared for consistency when a DNA fragment occurred in all six analyses and among the three DNA extraction methods.

DNA fingerprint analysis. The sarcosyl lysis-chloroform extraction-isopropanol precipitation method (Dellaporta et al., 1983) was used to extract DNA from the 25 buffalograss lines. The primers B-2 and B-20, which produced a moderate number of RAPD markers, were used for the DNA fingerprint analysis of the 25 buffalograss lines and were compared for RAPD marker identity between paired lines (number of unique RAPD markers in two buffalograss lines). RAPD markers were scored as present or absent, and only those amplified markers clearly present in the RAPD profiles of three separate agarose-gel electrophoresis analyses (independent DNA extractions) were included in the final analysis. The Jaccard similarity coefficients (Wilkinson, 1990) were calculated for the 25 buffalograss lines. The Jaccard similarity matrix was used to conduct a nearest-neighbor, hierarchical cluster analysis (Wilkinson, 1990).

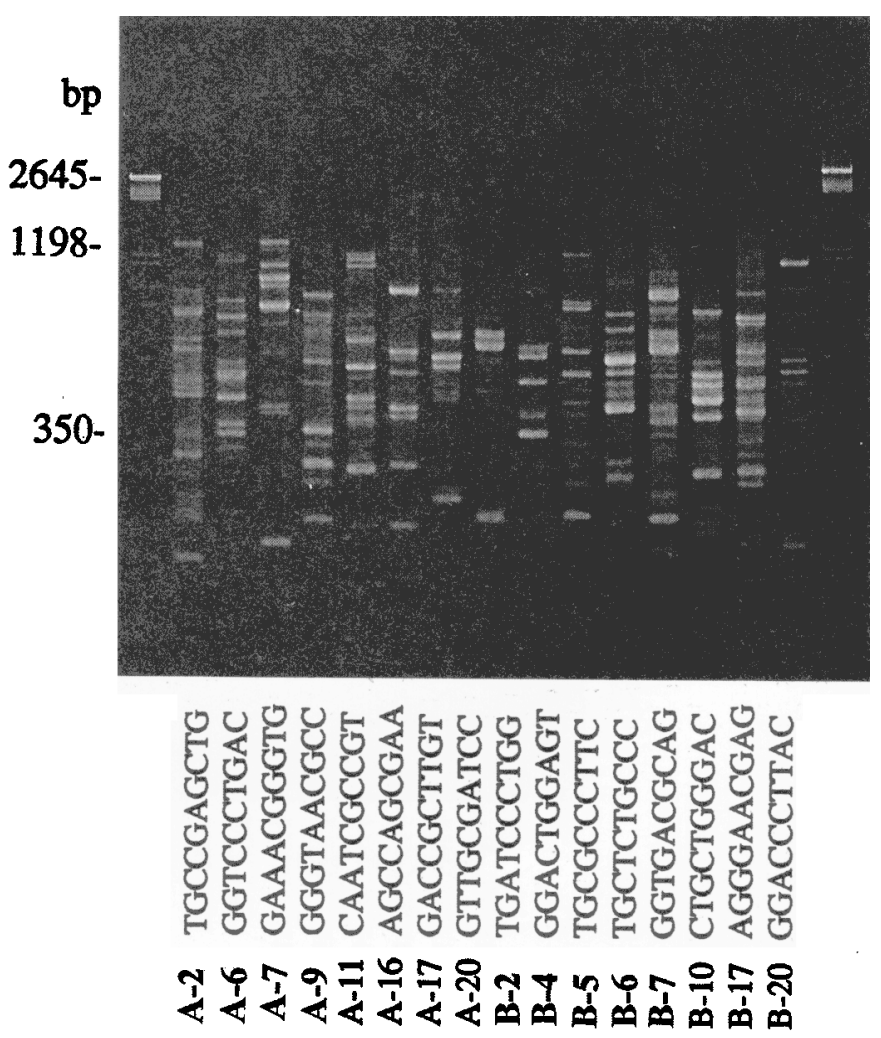

Fig. 1. RAPD profiles generated by 16 10-base nucleotide primers using genomic DNA extracted from Highlight 4 buffalograss. 


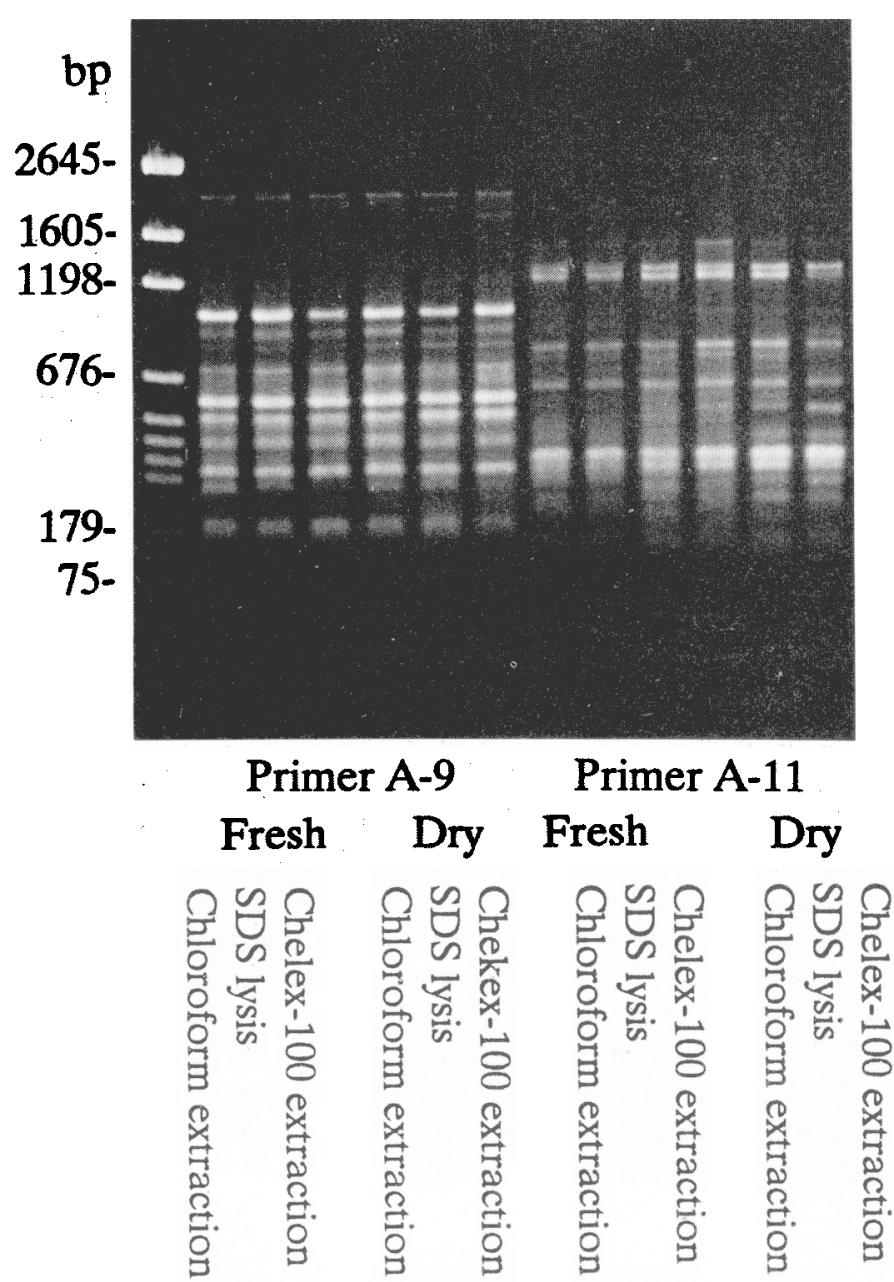

Fig. 2. Highly comparable RAPD profiles generated by primer A-9 or A-11 using Highlight 25 buffalograss genomic DNA extracted by the three DNA extraction methods and from fresh or dry leaf tissue.

\section{Results and Discussion}

The number of amplified DNA fragments produced by the 16 primers using Highlight 4 buffalograss ranged from six produced by primerA-16 to 22 produced by primerA-2 (Fig. 1). In the RAPD profiles generated from DNA extracted by the three DNA extraction methods, the size of the amplified DNA fragments produced by primerA-9 using DNA extracted from Highlight 25 buffalograss (Fig. 2) ranged from 179 to 1970 base pairs (BPs). The fragment size produced by primer A-11 ranged from 180 to 1198 BPs. DNA profiles produced by primers A-9 and A- 11 are markedly different, but the DNA profiles produced by the DNA extracted by the three extraction methods for either fresh or dry leaf tissues are highly similar. A total of 18 DNA fragments was produced by primer A9,15 of these DNA fragments appeared on all of the RAPD profiles of the three DNA extraction methods and the six replicate analyses. For primer A-11, 17 of the 20 DNA fragments detected appeared in all the three DNA extraction methods and the six replicate RAPD analyses. These results represent an $80 \%$. reproducibility and demonstrate that different DNA extraction methods, with as little as $5 \mathrm{mg}$ of oven-dried buffalograss leaf tissues, can be used for buffalograss DNA fingerprint analysis.

Among the 25 vegetatively propagated buffalograss lines, the size of the amplified DNA fragments produced by primer B-2 ranged from 309 to $1621 \mathrm{BPs}$ and those of primer B-20 ranged from 467 to 2280 BPs. A total of 12 DNA fragments (RAPD markers) were produced by primer B-2 and 20 fragments were produced by primer B-20. The number and size of DNA fragments found in the RAPD profiles varied among buffalograss lines. An example of the variation of RAPD profiles produced by primer B-20 among the 25 buffalograss lines is presented in Fig. 3. For primer B-2, $16 \%$. monomorphic DNA fragments was found among the 25 buffalograss lines. For primer B-20, no monomorphic DNA fragment was detected. The paired identity comparisons for RAPD markers produced by primers B- 2 and B-20 are presented in Tables 2 and 3 . The number 0 in the body of the tables indicates that identical

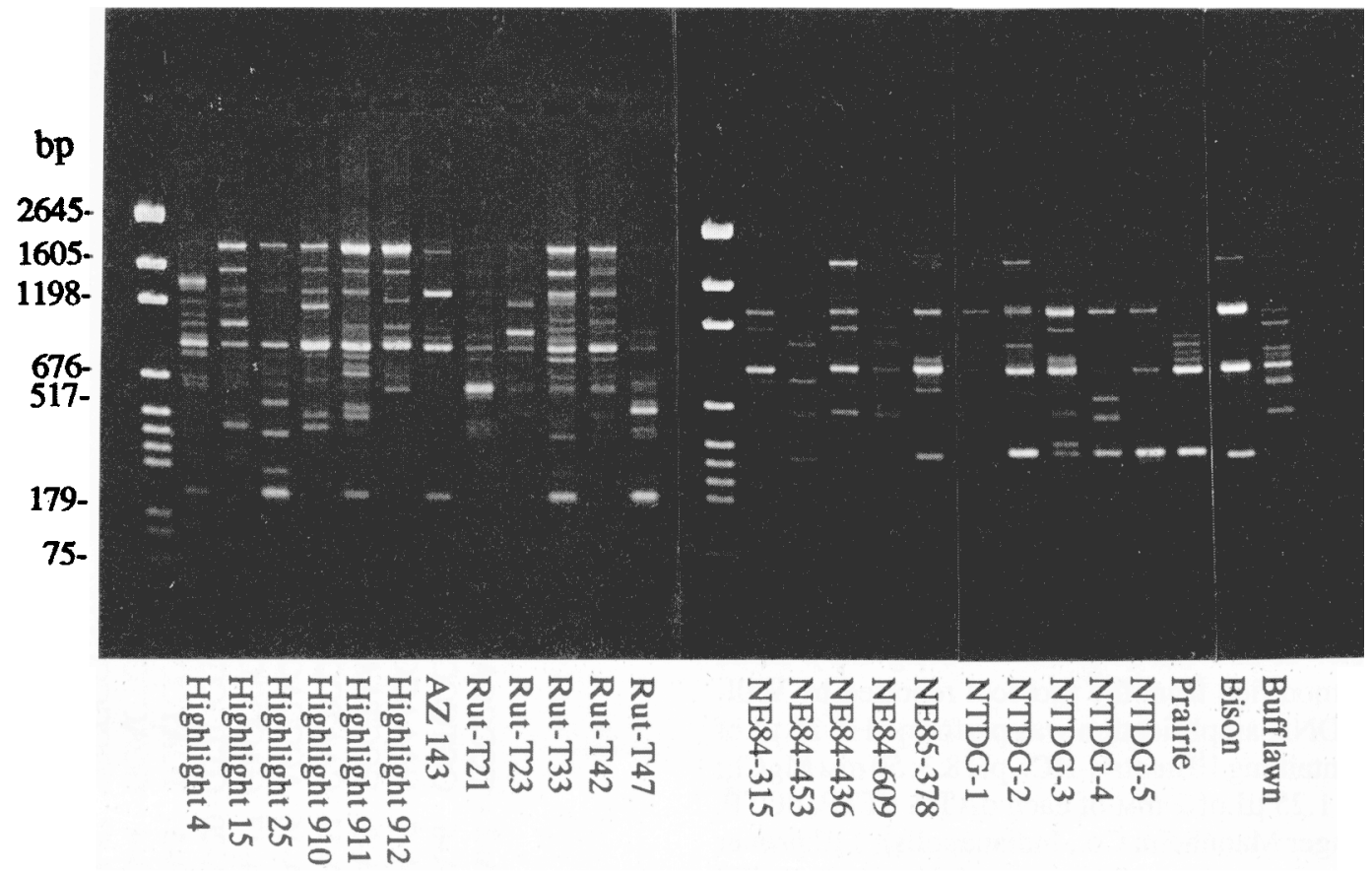

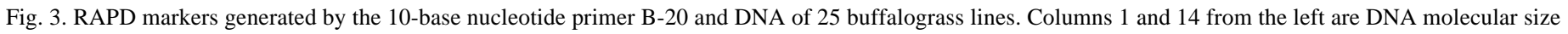
standards. 
Table 2. Pair-wise differences in random primer B-2-generated RAPD markers between the buffalograss cultivar breeding lines.

\begin{tabular}{|c|c|c|c|c|c|c|c|c|c|c|c|c|c|c|c|c|c|c|c|c|c|c|c|c|c|}
\hline \multicolumn{26}{|l|}{ Buffalograss } \\
\hline line & 1 & 2 & 3 & 4 & 5 & 6 & 7 & 8 & 9 & 10 & 11 & 12 & 13 & 14 & 15 & 16 & 17 & 18 & 19 & 20 & 21 & 22 & 23 & 24 & 25 \\
\hline 1. $\quad$ HL-4 & 0 & & & & & & & & & & & & & & & & & & & & & & & & \\
\hline 2. HL-15 & 1 & 0 & & & & & & & & & & & & & & & & & & & & & & & \\
\hline HL-25 & 3 & 2 & 0 & & & & & & & & & & & & & & & & & & & & & & \\
\hline 4. HL-92-27 & 3 & 4 & 4 & 0 & & & & & & & & & & & & & & & & & & & & & \\
\hline 5. HL-912 & 3 & 4 & 4 & 2 & 0 & & & & & & & & & & & & & & & & & & & & \\
\hline 6. HL-911 & 3 & 2 & 0 & 3 & 3 & 0 & & & & & & & & & & & & & & & & & & & \\
\hline 7. $\mathrm{AZ}-143$ & 0 & 1 & 3 & 3 & 4 & 3 & 0 & & & & & & & & & & & & & & & & & & \\
\hline 8. Rut.T-2-1 & 5 & 4 & 2 & 5 & 4 & 3 & 5 & 0 & & & & & & & & & & & & & & & & & \\
\hline 9. Rut.T-2-3 & 2 & 3 & 3 & 1 & 1 & 3 & 2 & 4 & 0 & & & & & & & & & & & & & & & & \\
\hline 10. Rut.T-3-3 & 3 & 2 & 2 & 5 & 4 & 2 & 3 & 2 & 5 & 0 & & & & & & & & & & & & & & & \\
\hline 11. Rut.T4-2 & 2 & 1 & 1 & 4 & 5 & 1 & 2 & 2 & 4 & 1 & 0 & & & & & & & & & & & & & & \\
\hline 12. Rut.T-4-7 & 3 & 2 & 2 & 5 & 4 & 2 & 3 & 2 & 5 & 0 & 1 & 0 & & & & & & & & & & & & & \\
\hline 13. NE84-315 & 3 & 2 & 0 & 3 & 4 & 0 & 3 & 2 & 3 & 2 & 1 & 2 & 0 & & & & & & & & & & & & \\
\hline 14. NE84-453 & 4 & 3 & 3 & 5 & 5 & 3 & 4 & 2 & 6 & 1 & 2 & 1 & 3 & 0 & & & & & & & & & & & \\
\hline 15. NE84-436 & 5 & 6 & 6 & 6 & 5 & 6 & 5 & 5 & 7 & 4 & 5 & 4 & 6 & 5 & 0 & & & & & & & & & & \\
\hline 16. NE84-609 & 3 & 4 & 2 & 3 & 2 & 2 & 3 & 1 & 3 & 2 & 3 & 2 & 2 & 3 & 4 & 0 & & & & & & & & & \\
\hline 17. NE85-378 & 1 & 2 & 4 & 4 & 3 & 4 & 1 & 3 & 3 & 2 & 3 & 2 & 4 & 3 & 4 & 2 & 0 & & & & & & & & \\
\hline 18. NTDG-1 & 2 & 1 & 1 & 4 & 5 & 1 & 2 & 3 & 4 & 1 & 0 & 1 & 1 & 2 & 5 & 3 & 3 & 0 & & & & & & & \\
\hline 19. NTDG-2. & 3 & 2 & 2 & 5 & 4 & 2 & 3 & 2 & 5 & 0 & 1 & 0 & 2 & 1 & 4 & 2 & 2 & 1 & 0 & & & & & & \\
\hline 20. NTDG-3 & 3 & 2 & 2 & 5 & 4 & 2 & 3 & 2 & 5 & 0 & 1 & 0 & 2 & 1 & 4 & 2 & 2 & 1 & 0 & 0 & & & & & \\
\hline 21. NTDG-4 & 2 & 1 & 3 & 3 & 5 & 3 & 2 & 5 & 4 & 3 & 2 & 2 & 3 & 2 & 7 & 5 & 3 & 2 & 3 & 3 & 0 & & & & \\
\hline 22. NTDG-5 & 1 & 2 & 2 & 3 & 4 & 2 & 1 & 4 & 3 & 2 & 1 & 2 & 2 & 3 & 4 & 2 & 2 & 1 & 2 & 2 & 3 & 0 & & & \\
\hline 23. Prairie & 2 & 1 & 1 & 4 & 5 & 1 & 2 & 3 & 4 & 1 & 1 & 1 & 1 & 2 & 5 & 3 & 3 & 0 & 1 & 1 & 2 & 1 & 0 & & \\
\hline 24. Bison & 2 & 3 & 3 & 5 & 3 & 3 & 2 & 3 & 4 & 1 & 2 & 1 & 3 & 2 & 3 & 1 & 1 & 2 & 1 & 1 & 4 & 1 & 2 & 0 & \\
\hline 25 Bufflawn & 3 & 5 & 5 & 2 & 5 & 6 & 4 & 5 & 5 & 5 & 6 & 5 & 4 & 7 & 5 & 4 & 6 & 5 & 6 & 6 & 5 & 4 & 5 & 5 & 0 \\
\hline
\end{tabular}

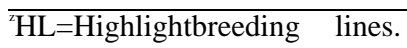

Table 3. Pair-wise differences in random primer B-20-generated RAPD markers between the buffalograss cultivar breeding lines.

\begin{tabular}{|c|c|c|c|c|c|c|c|c|c|c|c|c|c|c|c|c|c|c|c|c|c|c|c|c|c|}
\hline \multicolumn{26}{|l|}{ Buffalograss } \\
\hline line & 1 & 2 & 3 & 4 & 5 & 6 & 7 & 8 & 9 & 10 & 11 & 12 & 13 & 14 & 15 & 16 & 17 & 18 & 19 & 20 & 21 & 22 & 23 & 24 & 25 \\
\hline $\begin{array}{ll}1 . & \mathrm{HL}-4\end{array}$ & 0 & & & & & & & & & & & & & & & & & & & & & & & & \\
\hline 2. HL-15 & 10 & 0 & & & & & & & & & & & & & & & & & & & & & & & \\
\hline 3. HL-25 & 10 & 8 & 0 & & & & & & & & & & & & & & & & & & & & & & \\
\hline 4. HL-92-27 & 10 & 4 & 6 & 0 & & & & & & & & & & & & & & & & & & & & & \\
\hline 5. HL-912 & 9 & 7 & 5 & 7 & 0 & & & & & & & & & & & & & & & & & & & & \\
\hline 6. HL-911 & 9 & 7 & 7 & 9 & 6 & 0 & & & & & & & & & & & & & & & & & & & \\
\hline 7. $\mathrm{AZ}-143$ & 8 & 6 & 8 & 8 & 9 & 7 & 0 & & & & & & & & & & & & & & & & & & \\
\hline 8. Rut.T-2-1 & 6 & 6 & 4 & 6 & 5 & 5 & 4 & 0 & & & & & & & & & & & & & & & & & \\
\hline 9. Rut.T-2-3 & -8 & 8 & 6 & 6 & 9 & 7 & 8 & 6 & 0 & & & & & & & & & & & & & & & & \\
\hline 10. Rut.T-3=3 & 6 & 10 & 6 & 10 & 7 & 5 & 8 & 4 & 10 & 0 & & & & & & & & & & & & & & & \\
\hline 11. Rut.T 4-2 & 5 & 7 & 7 & 5 & 4 & 6 & 9 & 5 & 7 & 5 & 0 & & & & & & & & & & & & & & \\
\hline 12. Rut.T-4-7 & 12 & 6 & 4 & 8 & 7 & 5 & 8 & 6 & 8 & 8 & 9 & 0 & & & & & & & & & & & & & \\
\hline 13. NE84-315 & 10 & 12 & 6 & 8 & 9 & 11 & 8 & 8 & 10 & 8 & 11 & 10 & 0 & & & & & & & & & & & & \\
\hline 14. NE84-453 & 6 & 12 & 8 & 10 & 11 & 9 & 8 & 6 & 6 & 8 & 9 & 10 & 8 & 0 & & & & & & & & & & & \\
\hline 15. NE84-436 & 8 & 11 & 6 & 4 & 7 & 7 & 8 & 6 & $\mathrm{a}$ & 7 & 5 & 10 & 6 & 8 & 0 & & & & & & & & & & \\
\hline 16. NE84-609 & 9 & 9 & 7 & 9 & 10 & 4 & 7 & 7 & 5 & 9 & 10 & 7 & 7 & 5 & 5 & 0 & & & & & & & & & \\
\hline 17. NE85-378 & 7 & 7 & 11 & 6 & 12 & 14 & 7 & 9 & 9 & 11 & 10 & 13 & 9 & 6 & 9 & 10 & 0 & & & & & & & & \\
\hline 18. NTDG-1 & 7 & 7 & 7 & 7 & 10 & 8 & 5 & 7 & 7 & 9 & 8 & 9 & 7 & 5 & 7 & 4 & 6 & 0 & & & & & & & \\
\hline 19. NTDG-2 & 8 & 4 & 6 & 6 & 5 & 7 & 6 & 4 & 6 & 8 & 8 & 6 & 10 & 7 & 6 & 7 & 7 & 7 & 0 & & & & & & \\
\hline 20. NTDG-3 & 9 & 7 & 7 & 5 & 6 & 10 & 7 & 5 & 7 & 9 & 7 & 9 & 7 & 7 & 5 & 8 & 6 & 8 & 3 & 0 & & & & & \\
\hline 21. NTDG-4 & 7 & 7 & 7 & 7 & 8 & 6 & 7 & 7 & 7 & 9 & 8 & 7 & 9 & 7 & 7 & 4 & 8 & 4 & 5 & 6 & 0 & & & & \\
\hline 22. NTDG-5 & 9 & 5 & 7 & 5 & 10 & 8 & 5 & 7 & 7 & 11 & 10 & 7 & 7 & 7 & 7 & 4 & 6 & 2 & 5 & 6 & 2 & 0 & & & \\
\hline 23. Prairie & 8 & 8 & 12 & 10 & 13 & 9 & 6 & 8 & 8 & 10 & 11 & 8 & 10 & 6 & 12 & 7 & 7 & 5 & 8 & 9 & 7 & 5 & 0 & & \\
\hline 24. Bison & 10 & 6 & 10 & 10 & 11 & 12 & 6 & 8 & 8 & 10 & 11 & 10 & 10 & 8 & 10 & 9 & 5 & 5 & 6 & 5 & 7 & 5 & 4 & 0 & \\
\hline 25. Bufflawn & 8 & 10 & 6 & 8 & 11 & 7 & 6 & 6 & 6 & 6 & 9 & 8 & 6 & 8 & 4 & 5 & 9 & 7 & 8 & 7 & 7 & 7 & 10 & 8 & 0 \\
\hline
\end{tabular}

${ }^{\bar{H}} \mathrm{HL}=$ Highlight breeding lines. 


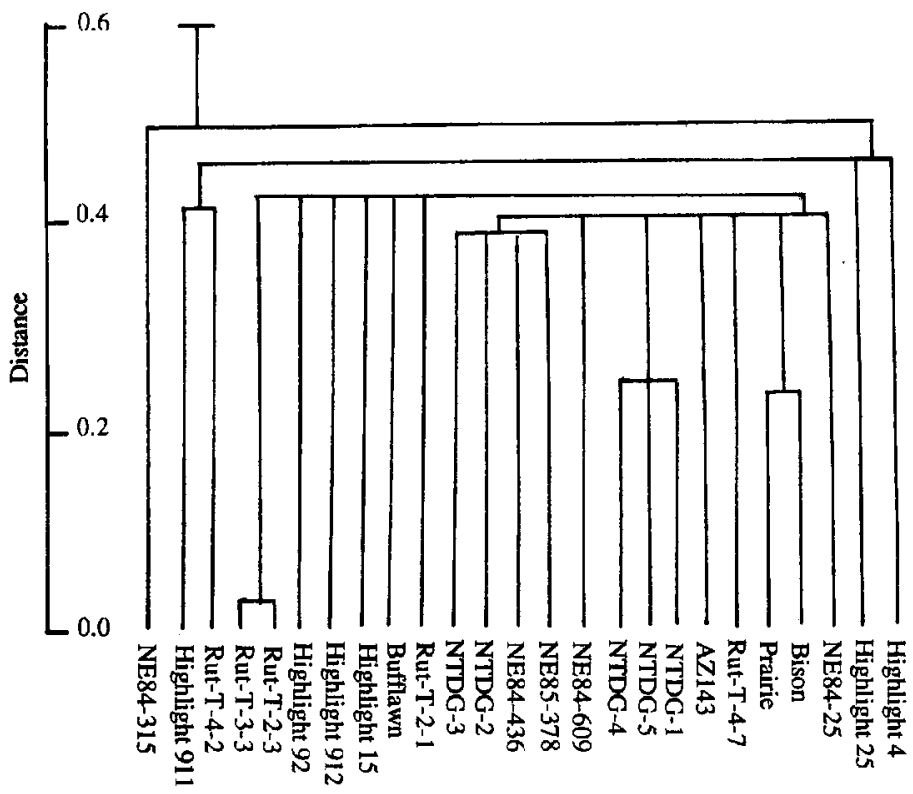

Fig. 4. Nearest neighbor clustering for the 25 buffalograss lines. Clustering based on Jaccard's similarity coefficient as calculated based on 32 RAPD DNA markers generated by B-2 and B-20 random primers.

DNA profiles of DNA fingerprints appeared between the two buffalograss lines. The rest of the numbers in the body of the two tables indicate the number of unique DNA fragments found between two buffalograss lines. Among the $299 \mathrm{BP}$ fingerprints produced by primerB-2, only 9 (3.3\%) were not distinguishable. For primer B-20, all 299 BP fingerprints were distinguishable. This represents a high resolution of identification for the buffalograss lines.

Results of the nearest-neighbor clustering analysis for the 25 vegetatively propagated buffalograss lines based on the RAPD markers generated by primers B-2 and B-20 are presented in Fig. 4. Generally, the 25 buffalograss lines fell into two groups: diploid and hexaploid. The cultivar Prairie (tetraploid) is in the hexaploid group. This result reflects the genetic diversity of this species.

The kinetics and characteristics of RAPD PCR are complex. Amplifying DNA in PCR may be significantly affected by temperature and $\mathrm{Mg}^{+2}$ concentration. In RAPD PCR, apart from these factors, the primer and template concentrations are evidently critical because they quantitatively affect the products (Kernodel et al., 1993). The primers and conditions for DNA amplification chosen for this study produced reasonably consistent RAPD markers and can be used to identify buffalograss cultivar breeding lines. However, more research is needed to established a more broadly applicable DNA fingerprint method for identifying turfgrasses.

The polymorphisms of the RAPD markers detected among the 25 vegetatively propagated buffalograss lines are extensive. The degree of polymorphism of the RAPD markers found in the buffalograss lines is much greater than that found in cultivars of vegetables such as in broccoli and cauliflower (Brassica oleracea L. Botrytis Group) (Hu and Quiros, 1991), in which $27.5 \%$ of the DNA bands were monomorphic across all cultivars tested. This difference may be due to the difference in the amount of genetic variation that exists between the different crops. The buffalograss lines are recently selected, and" they are derived from germplasm collected widely over Mexico and the United States. Therefore, a large amount of genetic variation at different phenotypic levels exists among the newly developed buffalograss lines.

\section{Literature Cited}

Clark, K.W., A. Hussain, K. Bamford, and W. Bushuk. 1989. Proc. 6th Intl. Turfgrass Res. Conf., Tokyo. p. 12-122.

Dellaporta, S.L., J. Wood, and J.B. Hicks. 1987. A plant molecular DNA minipreparation version. II. Plant Mol. Biol. Rpt. 1:19-21.

Edwards, K., C. Johnstone, and C. Thompson. 1991. A simple and rapid method for the preparation of plant genomic DNA for PCR analysis. Nucleic Acids Res. 19:6.

Gustave, C.A., J.B. Bassam, and P. M. Gresshoff. 1991. DNA amplification fingerprinting using very short arbitrary oligonucleotide primers. Biotechnology 9:553-556.

Hayward, M.D. and N.J. McAdam 1977. Isoenzyme polymorphism as a measure of distinctiveness and stability in cultivars of Lolium perenne. Z. Pflanzucht. 79:59-68.

Hu, J. and C.F. Quiros. 1991. Identification of broccoli and cauliflower cultivars with RAPD markers. Plant Cell Rpt. 10:505-511.

Jeffreys, A.J., V. Wilson, and S.I. Thein. 1985. Individual-specific fingerprints of human DNA. Nature 316:76-79.

Jeffreys, A. J., V. Wilson, R. Neuman, and J. Keyte. 1988. Amplification of human minisatellites by the polymerase chain reaction towards DNA fingerprinting of single cells. Nucleic Acids Res. 16: 10953-10971.

Kernodel, S. P., R.E. Cannon, and J.G. Scandalios. 1993. Concentration of primer and template qualitatively affects products in random-amplified polymorphic DNA PCR. Biotechnology 14:362-364.

Villamil, C.B., R.W. Duell, D.E. Fairbrothers, and J. Sadowski. 1982. Isoelectric focusing of esterase for fine fescue identification. Crop Sci. 22:786-793.

Walsh, P. S., D.A. Metzer, and R. Higuchi. 1991. Chelex 100 as a medium for simple extraction of DNA for PCR-based typing from forensic material. BioTechniques 10:506-513.

Wehner, J.D., J.M. Duich, and T.L. Watschke. 1976. Separation of Kentucky bluegrass cultivars using peroxidase isoenzyme banding patterns. Crop Sci. 16:476-479.

Wilkinson, J.F. and J.B. Beard. 1972. Electrophorestic identification of Agrostis palustris and Poa pratensis cultivars. Crop Sci. 12:833-834.

Williams, J. G. K., A.R. Kubelik, K.J. Livk, J.A. Rafalski, and S.V. Tingey. 1990. DNA polymorphisms amplified by arbitrary primers are useful as genetic markers. Nucleic Acids Res. 18:653-6535.

Wu, L. and R. Jampates. 1986. Chromosome number and isoenzyme variation in Kentucky bluegrass cultivars and plants regenerated from tissue culture. Cytologia 51:125-132.

Wu, L., M.A. Harivandi, and W.B. Davis. 1984. Identification of Kentucky bluegrass cultivars with esterase and phosphoglucomutase isoenzyme markers. Crop Sci. 24:763-768. 